\title{
Membranes and the response to insulin
}

By Helen M. Tepperman and Jay Tepperman, Department of Pharmacology, State University of New York, Upstate Medical Center, Syracuse, New York 13210, USA

There are several well-known examples of nutritionally-induced alterations in insulin response in humans and in experimental animals. High-fat diets (Himsworth, 1935; Blázquez \& Quijada, 1968; Ip et al. 1976; Lavau et al. 1979; Salans et al. 1981; Grundleger \& Thenen, 1982), obesity (Rabinowitz, 1970; Stauffacher et al. 197I) and starvation (Huber et al. 1965; Cahill et al. 1966; DiGirolamo \& Rudman, 1968) result in insulin resistance whether studied in intact animals or human subjects or in isolated target tissues and cells in vitro. On the other hand, a high-carbohydrate diet frequently increases insulin response (Himsworth, 1935; Olefsky \& Saekow, 1978; Kolterman et al. 1979a; Wigand et al. 1979). These alterations in insulin action are accompanied by adaptations of membrane structure and function as well as alterations in intracellular metabolic processes.

Emphasis in the present, selective review will be on changes in plasma membrane properties which may contribute to insulin resistance and their possible relation to the decreased effects of the hormone.

\section{Insulin receptor adaptations}

When, in the early 1970s, methods were devised for labelling insulin with radioactive iodine without altering its biological activity, many groups of investigators studied the insulin-binding capacity of various target cells in several states of insulin resistance. Interaction of insulin with its specific plasma membrane receptor is the necessary first step in its action and could be expected to influence its effect. Decreased insulin binding to fat cells of obese-hyperglycaemic mice was soon reported by Freychet et al. (1972) and to their liver plasma membranes by Kahn et al. (1972). Since then there have been numerous reports of decreased insulin binding in obese human subjects and experimental animals (e.g. Archer et al. 1973; Olefsky \& Reaven, 1975; Harrison et al. 1976). The reduced binding was accounted for by decreased numbers of available plasma membrane insulin receptors with unchanged affinity for insulin.

In obese human subjects, reduction of body-weight by fasting resulted in increased binding to monocytes (Bar et al. 1976; DeFronzo et al. 1978) and to adipocytes (Olefsky \& Reaven, 1975; Kolterman et al. 1979b) which was explained by an increased affinity of receptors for insulin after a short period of food deprivation and by an increased number of receptors after long periods of fasting. Refeeding reversed these effects. Several investigators have reported that subjecting rats to short periods of fasting increased insulin binding to adipocytes 
(Olefsky, 1976b) and hepatocytes (Trowbridge et al. 1984) by increasing receptor affinity for insulin. Fasting obese mice increased receptor number (Soll et al. 1975).

For many years we have been interested in metabolic adaptations of rats fed on various diets or fasted and refed. When methods became available for studying insulin binding, we compared adipocytes and liver plasma membranes from fat-fed rats with those from rats fed on diets with $67 \%$ of energy in the form of glucose. For both tissues, there was a marked decrease in binding when the rats had been fed on a $670 \mathrm{~g}$ lard $/ \mathrm{kg}$ diet for $5 \mathrm{~d}$ (Ip et al. 1976; Sun et al. 1977). Since then there have been additional reports of decreased insulin binding in fat-fed humans (Beck-Nielsen et al. 1978) and rats (Olefsky \& Saekow, 1978; Grundleger \& Thenen, 1982), although in some experimental conditions such binding effects have not been found even though fat-feeding decreased insulin response (Lavau et al. 1979; Salans et al. 1981). As shown in Fig. 1, the type of dietary fat can also influence insulin binding. When rats were fed on diets with $27 \%$ of energy as glucose and $46 \%$ as fat, insulin binding to their adipocytes was significantly less when the fat was hydrogenated coconut oil than when maize oil was given (C. Ip, H. M. Tepperman and J. Tepperman, unpublished results).

In some cases, changes in insulin binding are those expected as a result of down or up regulation, a high level of ambient insulin resulting in decreased insulin binding and a decreased level of insulin in increased binding (Roth et al. 1975). In obesity, for example, decreased binding is associated with hyperinsulinaemia (Rabinowitz, 1970; Freychet et al. 1972) whereas the increased binding of fasted rat tissues is accompanied by decreased levels of plasma insulin (Trowbridge et al.

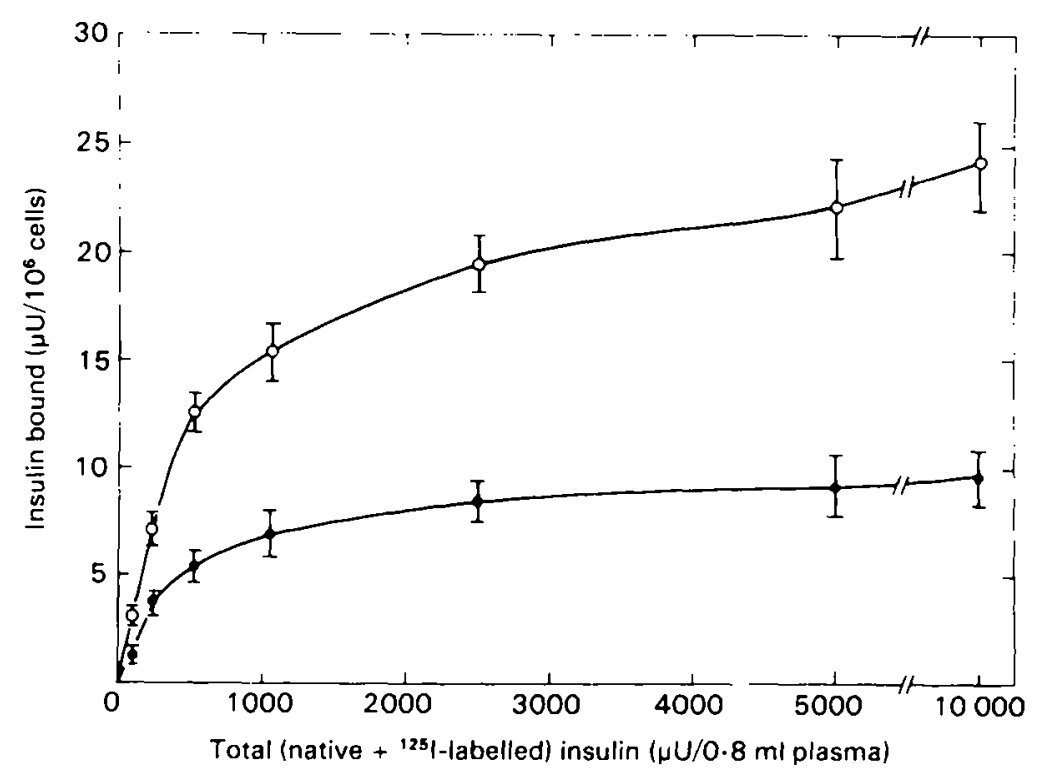

Fig. 1. Effect of type of dietary fat on insulin binding to rat adipocytes. Rats were fed on diets containing $46 \%$ of energy as maize oil $(O)$ or hydrogenated coconut oil $(O)$ for $7 \mathrm{~d}$. Values are means with their standard errors represented by vertical bars. Binding of ${ }^{125} \mathrm{I}$-labelled insulin $(50 \mu \mathrm{U} / \mathrm{ml})$ to adipocytes was carried out as described by lp et al. (1976). 
1984). Down regulation cannot, however, explain the decreased insulin binding of fat-fed rats in our experiments since insulin levels were not increased.

\section{Relation of insulin binding and effect}

The relation of insulin receptor adaptations to altered insulin response is complex. Several recent reviews have included discussions of this question (Olefsky, 1976a; Crettaz \& Jeanrenaud, 1980; Kahn, I980; Flier, 1983; Pi-Sunyer, r 983 ). In some states of insulin resistance, decreased insulin binding accompanies the diminished response; for example, in obesity. In our studies of fat-diet effects too, there was a correlation between changes in binding and response of adipocytes to insulin. Insulin-stimulated glucose oxidation was markedly reduced in fat-fed rats compared with those given glucose, in parallel with decreased insulin binding. Reversing the diets for an additional $5 \mathrm{~d}$ reversed both effects (Ip et al. 1976). Similarly, the decreased binding of adipocytes from rats fed on hydrogenated coconut oil compared with those from corn-oil-fed rats was associated with a decrease in insulin-stimulated glucose oxidation (C. Ip, H. M. Tepperman and J. Tepperman, unpublished results).

Recently, we have been interested in insulin stimulation of the production by plasma membranes of a low-molecular-weight substance which activates glycogen synthase (EC 2.4.I.II), phosphoprotein phosphatase (EC 3.1.3.16) and mitochondrial pyruvate dehydrogenase (PDH, EC 1.2.4.I) (Jarett \& Seals, 1979; Larner et al. 1979). We found (Fig. 2) that fat-feeding decreases this insulin stimulation, whether plasma membranes are prepared from rat adipocytes or from liver (Begum et al. 1982, 1983).

Although the changes in insulin binding and insulin response are in the same direction in obesity and fat feeding, there is considerable evidence that the binding

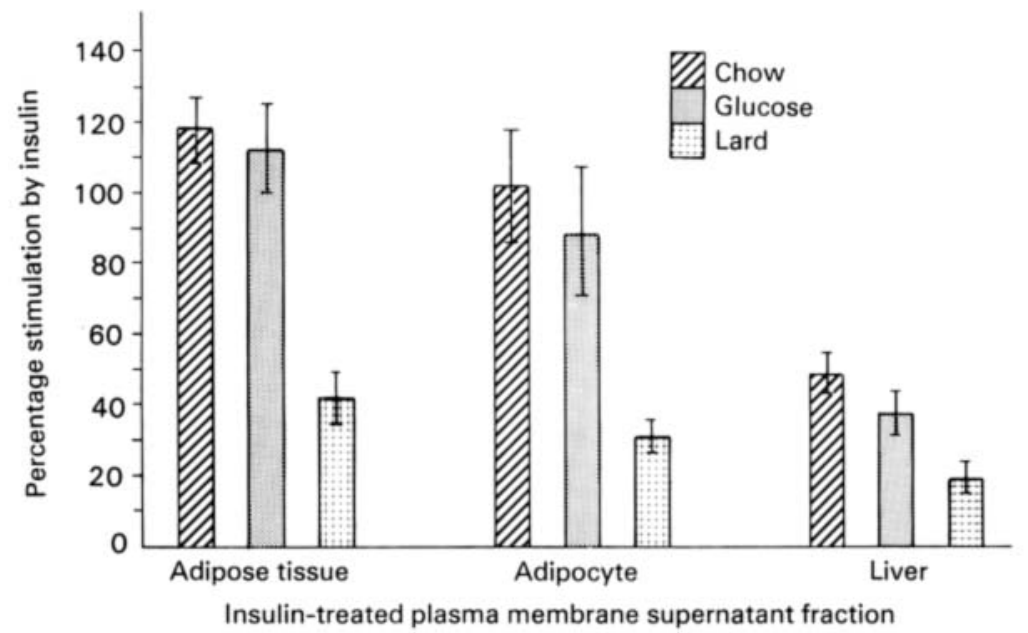

Fig. 2. Effect of diet on insulin stimulation of pyruvate dehydrogenase (PDH; EC 1.2.4.1) in adipose tissue and of the generation of PDH activator by adipocyte or liver plasma membranes. Values are means with their standard errors represented by vertical bars. Plotted from values of Begum et al. (1982, 1983$)$. 
defect is not the only factor involved in insulin resistance in these conditions. As has been emphasized by Kahn (1978), Olefsky (1981) and others, there are several possible patterns of insulin resistance. It is well-known that a maximum response to insulin is achieved when only a small fraction of the insulin receptors on the surface of target cells is occupied by the hormone (Kono \& Barham, 1971). If a moderate decrease in binding is nutritionally induced, the full response to insulin should still be observed when sufficient insulin is provided to occupy the necessary number of receptors. There would then be a shift to the right in the dose-response curve, a decrease in sensitivity, in the terminology proposed by Kahn (1978). Fig. 3, from Olefsky's ( $198 \mathrm{I}$ ) Lilly Lecture compares the insulin concentration response curves for two of the hormone's effects on adipocytes from lean and obese animals. Fig. $3(a)$ shows insulin stimulation of hexose transport as measured by 2-deoxyglucose uptake. The same maximum response is seen in adipocytes from both groups, but more insulin is required to produce it in adipocytes from the obese animals. This is the response to be expected from a reduction in insulin binding.

A different situation, shown in Fig. $3(b)$, exists when insulin stimulation of glucose oxidation is measured. The maximum effect of insulin is decreased in the cells from obese animals, a decrease in responsiveness, in Kahn's (1978) terminology. In the case of glucose oxidation, the decrease in insulin binding is not

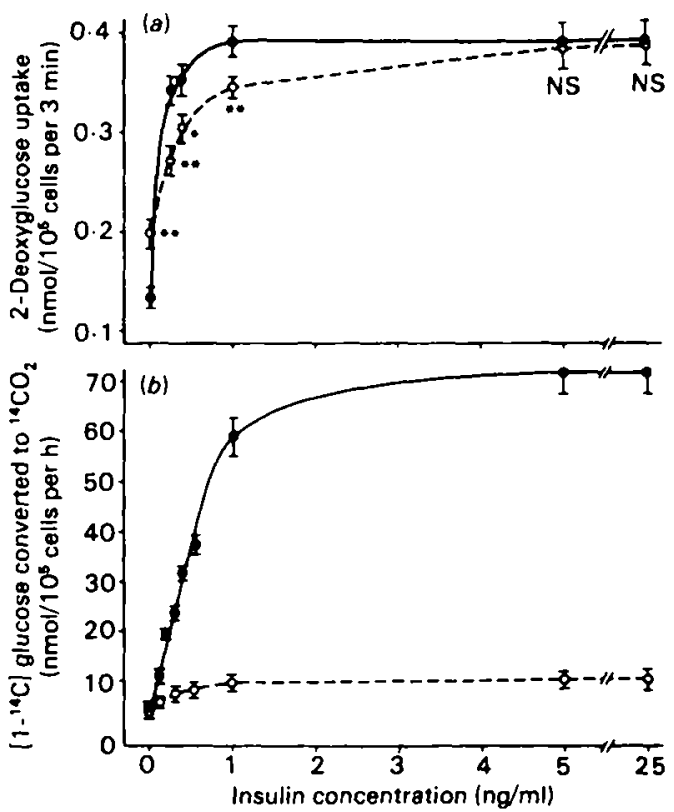

Fig. 3(a) Effectiveness of insulin to stimulate glucose transport in isolated adipocytes from lean $(O)$ and obese $(O)$ animals. Significantly different from value for lean animals: ${ }^{\bullet P}<0.05,{ }^{\bullet} \mathrm{P}<0.01$. NS, not significant. $(b)$ Effectiveness of insulin to stimulate $\left[1-{ }^{14} \mathrm{C}\right]$ glucose oxidation in adipocytes from lean $(O)$ and obese $(O)$ animals. Values are means with their standard errors represented by vertical bars. Reproduced from Olefsky ( $198 \mathrm{I}$ ), with permission from the American Diabetes Association, Inc. 
enough to explain the resistance. Post-receptor defects must be responsible. Others have also found evidence for post-binding defects in obesity (Czech et al. 1977; Crettaz \& Jeanrenaud, I980).

In our own studies of fat-fed rats there was also evidence for post-binding alterations. No amount of insulin could stimulate glucose oxidation in adipocytes from lard-fed rats as much as it did in rats given the glucose diet (Ip et al. 1976). The decrease in insulin responsiveness suggested post-receptor adaptations to the diet.

The situation is even more complex in some human subjects and rats after a period of starvation. Increased insulin binding to various target cells has been found by several investigators to be accompanied by insulin resistance rather than an increased response. For example, DeFronzo et al. (1978) found that obese human subjects showed increased insulin binding to monocytes after fasting, but a decreased glucose tolerance and insulin response in vivo. In fasted rats, increased binding to liver cells is accompanied by a decreased effect of insulin on the activity of glycogen synthase and on the production by plasma membranes of the PDH stimulator (Trowbridge et al. 1984). Adipocytes from fasted rats showed marked inhibition of insulin-stimulated glucose transport and oxidation in spite of increased binding capacity (Olefsky, 1976b; Kasuga et al. 1977). Clearly, post-binding effects are responsible for insulin resistance of starvation. Dissociation of insulin binding from response has been shown also in experiments in which the antilipolytic action of insulin seems to be unaffected although resistance to other insulin actions is found, for example, in obesity (Arner et al. I $98 \mathrm{r}$; Howard et al. 1984).

\section{Post-receptor plasma membrane adaptations}

Glucose transport. Post-binding adaptations could include plasma membrane alterations as well as changes in intracellular processes. In several insulin-resistant states, reported post-receptor modifications of plasma membrane structure and function could contribute to an altered response. One example is the reduced basal glucose transport activity we found in adipocytes from lard-fed rats compared with those from the glucose-fed group (Ip et al. 1977). Insulin-stimulated glucose transport was also diminished. The decreased insulin effect could be due in part to the lower basal level of activity. As Cushman and his collaborators have shown (Hissin et al. 1982), however, the decrease in glucose transporters available for recruitment is largely responsible for the resistance.

Phospholipids. Another type of membrane alteration has been described in fasted rats. It has recently been shown (Trowbridge et al. 1984) that $48 \mathrm{~h}$ starved rats had a decreased phospholipid: protein value in their liver plasma membranes. Fig. 4. shows this result along with other membrane lipid modifications. The membranes also exhibited increased microviscosity. In our studies of fat feeding, there were also changes in liver plasma membrane cholesterol content and phospholipid pattern (Sun et al. 1979). It is possible that these lipid changes could influence insulin response as well as contribute to binding changes. 


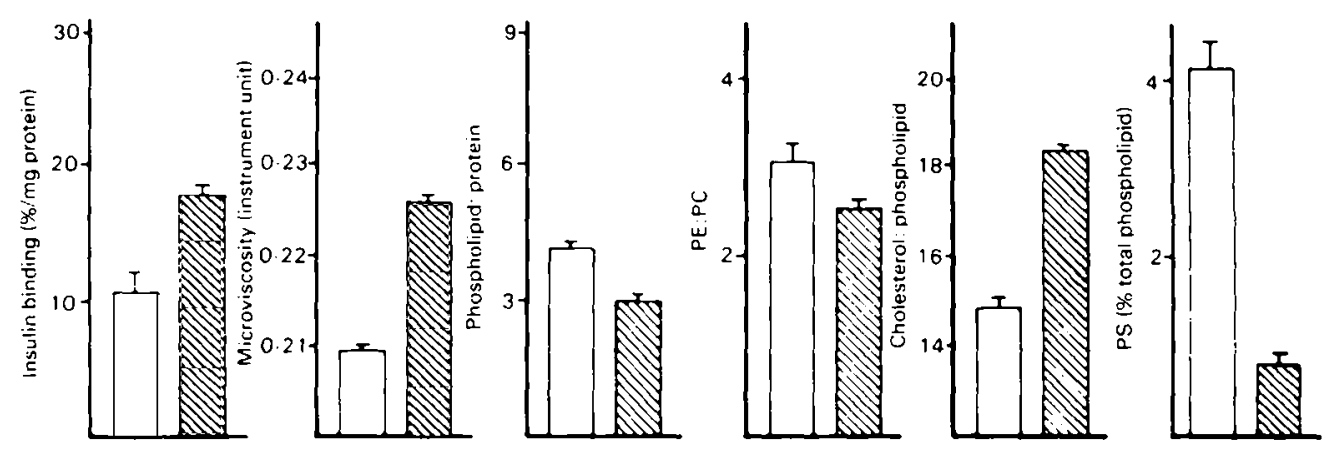

Fig. 4. Effect of fasting on hepatocyte plasma membrane fluidity, phospholipid composition and insulin binding to isolated plasma membranes. PC, phosphatidylcholine; PE, phosphatidylethanolamine; PS, phosphatidylserine. Values are means with their standard errors represented by vertical bars. Reprinted with permission from Trowbridge et al. ( 1984 ). ( $\square$ ), Fed; $\mathbb{\$}$, fasted.

Glycoproteins. One more type of plasma membrane modification found in several types of insulin resistance is an alteration in carbohydrate components. Chang et al. (1975) described reduced lectin binding to liver plasma membranes of obese hyperglycaemic mice. Both wheat-germ agglutinin, which binds $\mathrm{N}$-acetylglucosamine, and concanavalin $\mathrm{A}$, which combines with mannose, bound less well to membranes from obese mice than to control preparations, suggesting that a generalized change in membrane glycoproteins was associated with insulin resistance in these animals. In studies of adaptation to fat feeding, we also found a decrease in concanavalin A binding to liver plasma membranes (Henriquez et al. 1979). Furthermore, Carter and his associates (Chandramouli et al. 1977) have reported evidence for generalized changes in cell-surface carbohydrates in streptozotocin-diabetic rats. Insulin resistance has been observed in such rats by several investigators (Kasuga et al. 1978; Samson et al. 1982; Hansen et al. 1983). Amatruda \& Chang $\left(\mathrm{r}_{8} \mathrm{8}_{3}\right)$ recently reported that the insulin resistance of starvation and that of streptozotocin-diabetes included a decreased insulin generation of the PDH stimulation by liver plasma membranes; refeeding or insulin treatment (respectively) partially reversed this inhibition.

In an attempt to explain the changes in membrane carbohydrate of fat-fed rats, we measured the activities of several enzymes involved in glycoprotein synthesis. Our colleague, John Lucas (Lucas et al. 1980) found in adipocytes of lard-fed rats no decrease but an increase in activity of enzymes involved in the early steps of glycoprotein synthesis. However, we found decreases in the activities of several liver glycosyltransferases which participate in later stages of protein glycosylation. Fig. 5 shows the decreased activities of these enzymes in the livers of fat-fed rats and in those from rats with streptozotocin-diabetes (Tepperman et al. 1981, 1983) It seems possible that these enzyme changes contributed to the plasma membrane carbohydrate alterations in these animal models. 


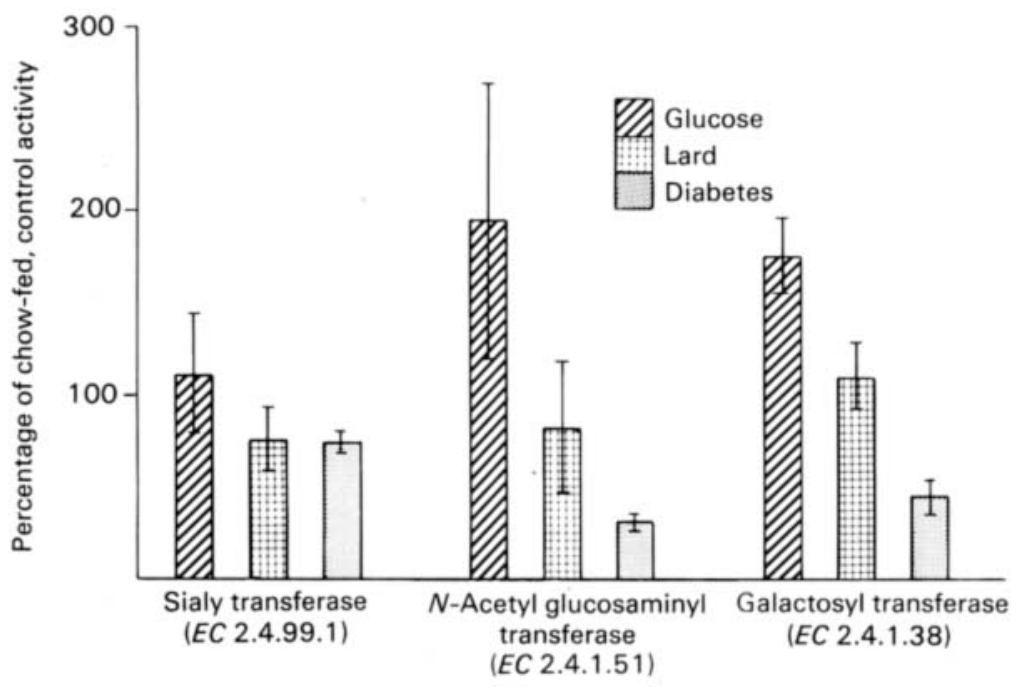

Fig. 5. Effects of diet and streptozotocin-diabetes on rat liver glycosyltransferases. Values are means with their standard errors represented by vertical bars. Plotted from values of Tepperman et al. (1981, 1983$)$.

Although it is known that both subunits of the insulin receptor are glycoproteins (for review, see Jacobs \& Cuatrecasas, I981), it seems that generalized alterations in plasma membrane carbohydrates cannot explain the insulin-binding alterations. Binding is increased in diabetic rat liver membranes (Cech et al. 1980; Samson et al. 1982) but decreased in fat feeding (Sun et al. 1977) although in both cases membrane carbohydrate is decreased. (There could possibly be more specific changes in receptor carbohydrate metabolism not yet detected in these animal models to account for these observations.) However, it does seem likely that membrane carbohydrate alterations could contribute to post-receptor modifications of some actions of insulin. Cuatrecasas \& Illiano (1971) showed that treatment of rat fat cells with neuraminidase $(E C$ 3.2.1.18) to remove sialic acid residues decreased the insulin effect on glucose oxidation at concentrations which did not alter hormone binding. That suggested that at least some carbohydrate residues are more important for insulin action than for its attachment to its receptor. Recently, we found evidence that membrane carbohydrate may be important in insulin generation of the PDH stimulator (Begum et al. 1983). As shown in Fig. 6, treatment of supernatant fractions from insulin-treated liver membranes with either neuraminidase or $\beta$-galactosidase ( $E C$ 3.2.1.23) decreased the mediator activity.

\section{Post-membrane adaptations}

Thus, nutritionally induced changes in plasma membrane insulin binding, in glucose transport capacity, in lipid composition and in glycoproteins could contribute to certain types of insulin resistance. Adaptations inside cells undoubtedly play a role as well, as several investigators have pointed out (see 


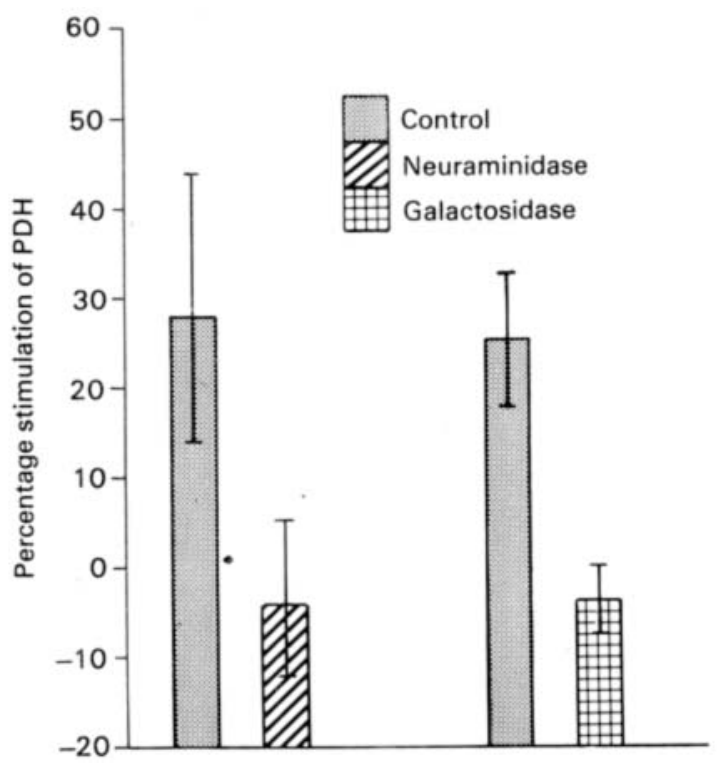

Fig. 6. Effect of glycosidases on insulin-induced pyruvate dehydrogenase (PDH, EC 1.2.4.1) activator. Supernatant fractions from insulin-treated liver membranes were incubated with or without neuraminidase $(E C 3.2 .1 .18 ; 100 \mu \mathrm{g} / \mathrm{ml})$ or $\beta$-galactosidase $(E C 3.2 .1 .23 ; 4 \mu \mathrm{U} / \mathrm{ml})$, then assayed for PDH. Values are means with their standard errors represented by vertical bars. Plotted from values of Begum et al. (1983).

reviews mentioned previously). In our first study of insulin binding (Ip et al. 1976), we found some evidence for a contribution of intracellular adaptations to the decreased insulin stimulation of glucose oxidation in adipocytes from fat-fed rats. When specific glucose transport was no longer limiting because very high concentrations of glucose were present in the medium, there was still a diminished capacity for oxidizing glucose when comparisons were made to the performance of cells from glucose-fed rats. Altered intracellular processes must have been involved to produce this result. Such adaptations have been reported, in fact, by many investigators who have studied nutritional effects on the activities of a variety of cytosolic enzymes in various insulin-resistant states (Leveille, 1970; Tepperman \& Tepperman, 1970).

Experiments carried out in our laboratory were supported by NIH Grant $A M-054 \mathrm{IO}$ and USPHS Grant RR-05402.

\section{REFERENCES}

Amatruda, J. M. \& Chang, C. L. (1983). Biochemical and Biophysical Research Communications I I2, 35-4I.

Archer, J. A. Gorden, P., Gavin, J. R. Lesniak, M. A. \& Roth, J. (1973). Fournal of Clinical Endocrinology and Metabolism 36, 627-633.

Arner, P., Bolinder, J., Engfeldt, P. \& Ostman, J. (1981). Metabolism 30, 753-760.

Bar, R. S., Gorden, P., Roth, J. Kahn, C. R. \& DeMeyts, P. (1976). Fournal of Clinical Investigation 58, 1123-11 35 . 


\section{Vol. 44 Nutritional aspects of membrane structure and function}

Beck-Nielsen, H., Pedersen, O. \& Sørensen, N. S. (1978). Diabetologia 15, 289-296.

Begum, N., Tepperman, H. M. \& Tepperman, J. (1982). Endocrinology 110, 1914-192 I.

Begum, N., Tepperman, H. M. \& Tepperman, J. (1983). Endocrinology $112,50-59$.

Blazquez, E. \& Quijada, C. L. (1968). Fournal of Endocrinology 42, 489-494.

Cahill, G. F. Jr, Herrera, M. G., Morgain, A. P., Soeldner, J. S., Steinke, D., Levy, P. L., Reichard, G. A. Jr \& Kipnis, D. M. (1966). Fournal of Clinical Investigation 45, 1 75 1-1769.

Cech, J. M., Freeman, R. B. Jr, Caro, J. F. \& Amatruda, J. M. (1980). Biochemical fournal 188, $839-845$.

Chandramouli, V., Williams, S., Marshall, J. S. \& Carter, J. R. Jr (1977). Biochimica et Biophisica Acta $465,19-33$.

Chang, K., Huang, D. \& Cuatrecasas, P. (1975). Biochemical and Biophysical Research Communications 64, 566-573.

Crettaz, M. \& Jeanrenaud, B. (1980). Metabolism 29, 467-473.

Cuatrecasas, P. \& Illiano, G. (197I). Fournal of Biological Chemistry 246, 4938-4946.

Czech, M. P., Richardson, D. K. \& Smith, C. J. (1977). Metabolism 26, 1057-1077.

DeFronzo, R. A., Soman, V., Sherwin, R. S., Hendler, R. \& Felig, P. (1978). Fournal of Clinical Investigation 63, 204-212.

DiGirolamo, M. \& Rudman, D. (1968). Endocrinology 82, I133-1141.

Flier, J. S. (1983). Annual Review of Medicine 34, 145-160.

Freychet, P., Laudat, M. H., Laudat, P., Rosselin, G., Kahn, C. R., Gorden, P. \& Roth, J. (1972). FEBS Letters 25, 339-342.

Grundleger, M. L. \& Thenen, S. W. (1982). Diabetes 31, 232-237.

Hansen, F. M., Nilsson, P., Sonne, O., Hustvedt, B.-E., Nilsson-Ehle, P., Nielsen, J. H. \& Løvø, A. (1983). Diabetologia 24, 131-135.

Harrison, L. C., Martin, F. I. R. \& Melck, R. A. (1976). Journal of Clinical Investigation 58, I $435^{-1} 144^{1}$.

Henriquez, D. S., Tepperman, H. M. \& Tepperman, J. (1979). Fournal of Lipid Research 20, $624-630$.

Himsworth, H. P. (1935). Clinical Science 2, 67-94.

Hissin, P. J., Karnieli, E., Simpson, I. A., Salans, L. B. \& Cushman, S. W. (1982). Diabetes 31, $589-592$.

Howard, B. V., Klimes, I., Vasquez, B., Brady, D., Nagulesparan, M. \& Unger, R. H. (1984). fournal of Clinical Endocrinology and Metabolism 58, 544-548.

Huber, A. M., Gershoff, S. N. \& Antoniades, H. N. (1965). Metabolism 14, 6r9-624.

Ip, C., Tepperman, H. M., Dewitt, J. \& Tepperman, J. (1977). Hormone and Metabolic Research 9, $218-222$.

Ip, C., Tepperman, H. M., Holohan, P. \& Tepperman, J. (1976). Fournal of Lipid Research 17, 588-598.

Jacobs, S. \& Cuatrecasas, P. (1981). Endocrine Reviews 2, $25^{1-263}$.

Jarett, L. \& Seals, D. R. (1979). Science 206, $1407-1408$.

Kahn, C. R. (1978). Metabolism 27, Suppl. 2, 1893-1902.

Kahn, C. R. (1980). Metabolism 29, 455-466.

Kahn, C. R., Neville, D. M. Jr, Gorden, P., Freychet, P. \& Roth, J. (1972). Biochemical and Biophysical Research Communications 48, $135^{-1} 42$.

Kasuga, M., Akanuma, Y., Iwamoto, Y. \& Kosaka, K. (1977). Endocrinology 100, 1 $3^{8} 4^{-1} 390$.

Kasuga, M., Akanuma, Y., Iwamoto, Y. \& Kosaka, K. (1978). American fournal of Physiology 235, Er $75-E_{1} 82$.

Kolterman, O. G., Greenfield, M., Reaven, G. M., Saekow, M. \& Olefsky, J. M. (1979a). Diabetes 28, $73^{\mathrm{r}}-73^{6}$.

Kolterman, O. G., Saekow, M. \& Olefsky, J. M. (1979b) fournal of Clinical Endocrinology and Metabolism 48, 836-842.

Kono, T. \& Barham, F. W. (1971). Journal of Biological Chemistry 246, 6210-62 I6.

Larner, H., Galasko, G., Cheng, K., DePaoli-Roach, A. A., Huang, L., Daggy, P. \& Kellog, J. (1979). Science 206, 1408-1410.

Lavau, M., Fried, S. K., Susini, C. \& Freychet, P. (1979). Fournal of Lipid Research 20, 8-16.

Leveille, G. (1970). Federation Proceedings 29, $1294^{-1} 3^{01}$.

Lucas, J. J., Tepperman, H. \& Tepperman, J. (1980). Biochemical fournal 186, 791-798. 
Olefsky, J. M. (1976a). Diabetes 25, I I54-1162.

Olefsky, J. M. (1976b). Fournal of Clinical Investigation 58, 1450-1460.

Olefsky, J. M. (1981). Diabetes 30, 148-162.

Olefsky, J. M. \& Reaven, G. M. (1975). Endocrinology 96, $1486-1498$.

Olefsky, J. M. \& Saekow, M. (1978). Endocrinology 103, 2252-2263.

Pi-Sunyer, F. X. (1983). Current Concepts in Nutrition 12, 1 I $1-127$.

Rabinowitz, D. (1970). Annual Review of Medicine 21, 24 1-258.

Roth, H., Kahn, C. R., Lesniak, M. A., Gorden, P., DeMeyts, P., Megyesi, K., Neville, D. M. Jr, Gavin, J. R., Soll, A. H., Freychet, P., Goldfine, I. D., Bar, R. S. \& Archer, J. A. (I975). Recent Progress in Hormone Research 31, 95-1 39.

Salans, L. B., Foley, J. E., Wardzala, L. J. \& Cushman, S. W. (I98I). American fournal of Physiology 240, E $175-\mathrm{E}_{1} 8_{3}$.

Samson, M., Fehlmann, M., Morin, O., Dolais-Kitabgi, J. \& Freychet, P. (I982). Metabolism 3 I, $766-77^{2}$.

Soll, A. H., Kahn, C. R., Neville, D. M. Jr \& Roth, J. (1975). Fournal of Clinical Investigation 56, $769-780$.

Stauffacher, W., Orci, L., Dameron, D. P., Bun, I. M. \& Renold, A. E. (1971). Recent Progress in Hormone Research 27, 4 I-95.

Sun, J. V., Tepperman, H. M. \& Tepperman, J. (1977). Fournal of Lipid Research 18, 533-539.

Sun, J. V., Tepperman, H. M. \& Tepperman, J. (1979). Journal of Nutrition 109, 193-201.

Tepperman, H. M., Dewitt, J. \& Tepperman J. (1983). Diabetes 32, 412-4I 5 .

Tepperman, H. M., Silver, R., Dewitt, J. \& Tepperman, J. (1981). Fournal of Nutrition III, $1734-1741$.

Tepperman, J. \& Tepperman, H. M. (1970). Federation Proceedings 29, 1284-1293.

Trowbridge, M., Sussman, A., Ferguson, L., Draznin, B., Neufeld, N., Begum, N., Tepperman, H. \& Tepperman, J. (1984). Molecular and Cellular Biochemistry 62, 25-36.

Wigand, J. P., Anderson, J. H. Jr, Jennings. S. S. \& Blackard, W. G. (1979). American fournal of Clinical Nutrition 32, 6-9. 